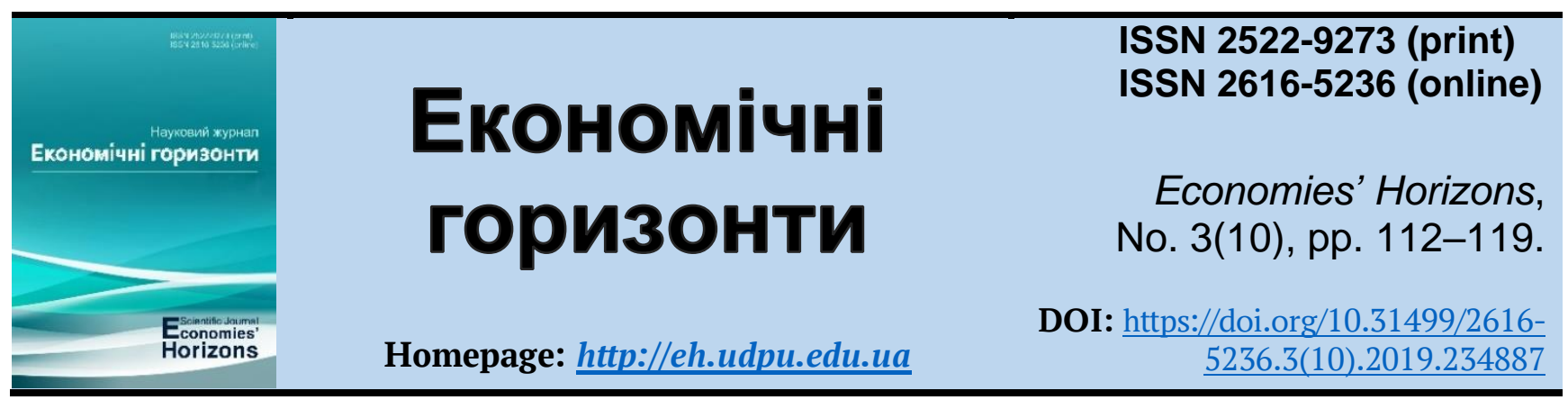

UDC 330.56:656.07

\title{
A regional assessment of trends in business development in Ukraine
}

\author{
Iryna I. Nadtochii ${ }^{1}$, Cand. Ec. Sc., Associate Professor
}

Received: 8 August 2019

Accepted: 12 September 2019
Nadtochii, I. I. (2019), "A regional assessment of trends in business development in
Ukraine", Economies' Horizons, no. 3(10), pp. 112-119, doi: https://doi.org/10.31499/2616-5236.3(10).2019.234887

Abstract. The purpose of the research. The purpose of the article is to assess regional trends in business development in Ukraine. Methodology. The theoretical and methodological basis of the study is the scientific works of scientists in the field of business development in Ukraine. To achieve this goal, the following research methods were used: PEST-analysis of the external environment of SME development in the regions; methods of statistical analysis - to assess changes in the dynamics of GRP for 2014-2018. Results. It is investigated that from 2016 until in Ukraine there was a certain economic recovery, which is confirmed by the growth of consumption and income, as well as the growth of consumer lending and remittances. But in 2018, there was a decrease in exports and imports of goods and services. Exports decreased by $2.8 \%$ of GDP, and imports by $1.9 \%$ of GDP compared to the previous 2017 year. The decline in exports is due to weakening external demand for domestic goods and services. Despite some difficulties, a number of reforms have been implemented in Ukraine, which has had a positive impact on the economic situation. Reforms in Ukraine are supported by the international community. In 2018, the IMF provided Ukraine with a reserve loan for a period of 14 months in the amount of 3.9 billion USD. Ukraine received 4.4 billion USD in EU macro-financial assistance US and a loan of 349 million EUR under the World Bank Guarantee to ensure economic development. After the crisis of the economy in 2014, Ukraine managed to restore macroeconomic stability by adhering to flexible exchange rate limits, tight fiscal policy, financial and energy reforms. The signing of the Association Agreement with the EU in 2014 on the establishment of a Deep and Comprehensive Free Trade Area with the EU had a positive impact on Ukraine's economy. It is investigated that in 2018 the share of micro, small and medium enterprises (SMEs) in Ukraine was over $90 \%$ of the total number of enterprises. SMEs provided more than $60 \%$ of jobs and almost $50 \%$ of value-added in the business sector. More than $50 \%$ of the SME structure is concentrated in wholesale and retail trade. The downside is the fact that most SMEs are concentrated in a low value-added sector of the economy. However, the share of SMEs engaged in IT technologies has been growing rapidly over the last five years. Wholesale and retail trade have the largest share (43.1\%) in the structure of small and medium enterprises in the Odessa region. Practical meaning. The results of the analysis will allow the authorities of the country and its individual territories to develop the necessary measures to improve business conditions, improve living standards and ensure the effectiveness of economic development of the territory. Prospects for further research. Development of an economic mechanism for the transformation of business processes in the system of competitive development of territories.

\footnotetext{
${ }^{1}$ Admiral Makarov National University of Shipbuilding, Kherson Branch; Associate Director for Education and Research; ORCID ID: https://orcid.org/0000-0003-0693-8000; e-mail: management@nuos.edu.ua.
} 

region.

Key words: business process, business, national features, regional features, evaluation, Odesa JEL Classification: M10; M13; R00; R58

Number of references: 11; number of tables: 3; number of figures: $\mathbf{0}$; number of formulas: $\mathbf{0 .}$

\title{
Регіональна оцінка тенденцій розвитку бізнесу в Україні
}

\author{
Ірина Ігорівна Надточій ${ }^{1}$, к. е. н., доцент
}

Стаття надійила: 08.08.2019 Стаття прийнята: 12.09.2019
Nadtochii I. I. A regional assessment of trends in business development in Ukraine. Економічні горизонти. 2019. № 3(10). C. 112-119. DOI: $\underline{10.31499 / 2616-5236.3(10) .2019 .234887 ~}$

Анотація. Метою статті $\epsilon$ оцінювання регіональних тенденцій розвитку бізнесу в Україні. Методологія. Теоретичною і методологічною основою дослідження $\epsilon$ наукові праці вчених у сфері розвитку бізнесу в Україні. Для досягнення поставленої в роботі мети були використані такі методи дослідження: PEST-аналіз зовнішнього середовища розвитку МСБ у регіонах; методи статистичного аналізу - для оцінювання зміни динаміки ВРП за 2014-2018 роки. Результати. Досліджено, що з 2016 року в Україні спостерігалося певне економічне відновлення, яке підтверджується зростанням рівня споживання та доходів населення, а також зростанням споживчого кредитування і грошових переказів. Але У 2018 році було зафіксовано зменшення рівня експорту та імпорту товарів та послуг. Експорт скоротився на 2,8 \% від ВВП, а імпорт на 1,9 \% від ВВП порівняно із попереднім 2017 роком. Скорочення експорту викликане послабленням зовнішнього попиту на вітчизняні товари і послуги. Незважаючи на певні негаразди, в Україні було здійснено ряд реформ, які позитивно вплинули на економічний стан. Здійснення реформ в Україні відбувається за підтримки міжнародної спільноти. У 2018 р. МВФ надав Україні резервне кредитування строком на 14 місяців у розміні 3,9 млрд дол. США. Україна отримала Макрофінансову допомогу ЄС на суму 4,4 млрд дол. США та позику 349 млн євро під Гарантію Світового Банку для забезпечення економічного розвитку. Після кризового стану економіки 2014 року в Україні вдалося поновити макроекономічну стабільність за рахунок дотримання гнучких меж обмінного валютного курсу, жорсткої фіскальної політики, фінансової та енергетичної реформ. Позитивно вплинуло на економіку України підписання у 2014 р. Угоди про асоціацію з ЄС стосовно створення Поглибленої та всеохоплюючої зони вільної торгівлі 3 $€ С$. Досліджено, що за 2018 рік в Україні питома вага мікро, малих та середніх підприємств (МСП) становила понад 90 \% загальної кількості підприємств. МСП забезпечувало понад 60 \% робочих місць і майже 50 \% доданої вартості у бізнес-секторі. Понад 50 \% у структурі МСП зосереджено у торгівлі оптовій та роздрібній. Негативний $є$ той факт, що більша частка МСП зосереджені у секторі економіки, який характеризується низьким рівнем доданої вартості. Проте за останні п'ять років швидко зростає частка підприємств МСП, що займаються IT технологіями. Оптова та роздрібна торгівля займає найбільшу питому частку $(43,1 \%)$ і у структурі суб'єктів малого та середнього підприємництва у Одеській області. Практичне значення. $P e^{-}$ зультати аналізу дозволять владним структурам країни та окремих їі територій розробити необхідні заходи для поліпшення умов ведення бізнесу, для покращення рівня життя населення та для забезпечення ефективності економічного розвитку окремої території. Перспективи подальщих досліджень. Розроблення економічного механізму трансформації бізнес процесів у системі забезпечення конкурентного розвитку територій.

\footnotetext{
${ }^{1}$ Національний університет кораблебудування імені адмірала Макарова, Херсонська філія; заступник директора з навчально-методичної та наукової роботи; ідентифікатор ORCID: https://orcid.org/00000003-0693-8000; e-mail:management@nuos.edu.ua.
} 
Ключові слова: бізнес-процес, бізнес, національні особливості, регіональні особливості, оцінювання, Одеська область.

Кількість джерел: 11; кількість таблиць: 3; кількість рисунків: 0; кількість формул: 0.

\section{Introduction.}

The level of business development, the socio-economic situation of the regions and the state of the national economy are very closely interrelated. Assessment of the main trends of regional development is an important step in building strategic programs. The most important generalizing characteristic of regional development is the value of gross regional product (GRP), which characterizes the measurement in monetary terms of all products produced during the year in the region.

\section{Literature review.}

Analysis of recent research and publications on the problem. Among modern economists, whose research is devoted to the problems of business process management in the system of competitive development of territories, it is necessary to note scientific works, in particular: S. Afontsev (2001), E. Khesin (2005), R. Shchenin and S. Smirnov (2005), I. Kramarenko (2014) N. Khokhlov (2004) and others. However, the complexity and versatility of this study requires a global comparison of national characteristics of business development in Ukraine, taking into account the spatial asymmetry.

\section{Methodology.}

The theoretical and methodological basis of the study are the scientific works of scientists in the field of business development in Ukraine. To achieve this goal, the following research methods were used: PESTanalysis of the external environment of SME development in the regions; methods of statistical analysis - to assess changes in the dynamics of GRP for 2014-2018.

\section{Research objectives.}

The purpose of the article is to assess regional trends in business development in Ukraine.

\section{Results and discussions.}

Presentation of the main results and their substantiation. According to a national estimate: "in 20 regions (74\% of the country's population or 31.4 million people in 2017) the gross regional product per capita is lower than the average in Ukraine. The growth of disparities is influenced by the long-term unresolved problems of territories with unfavorable socio-economic conditions" (Ministry for Communities and Territories Development of Ukraine, 2019).

The dynamics of gross regional product, thus by the beginning of 2019 showed a gradual increase in all regions without exception (Table 1). The city of Kyiv with a developed industry, construction and transport is the undisputed leader among the regions of Ukraine in terms of GRP. Among the regions, the leading position belongs to the Dnipropetrovsk region due to the developed mining industry, agriculture, construction and metallurgy with energy. In addition, this area is famous for its reserves of useful and fuel and energy resources. The smallest value of GRP is in Chernivtsi region, where there is a significant decline in industrial activity, which is accompanied by relative scarcity of natural resources and the predominance of mountainous areas, which is not suitable for agricultural development.

For areas with poorly developed industry, low production and resource potential, small and medium-sized businesses (SMEs) can serve as a driving force for economic development. The emphasis on the development of small and medium-sized businesses in such regions can help solve a number of not only economic but also social problems.

Small and medium business in Ukraine corresponds to "about $64 \%$ of value added, $81.5 \%$ of employees in businesses and $37 \%$ of tax revenues" (Government portal, 2019). 
Nadtochii I. I. A regional assessment of trends in business development in Ukraine

Table 1. Dynamics of GRP for 2014-2018

\begin{tabular}{|c|c|c|c|c|c|c|c|}
\hline \multirow{2}{*}{ Region } & \multicolumn{5}{|c|}{$\begin{array}{c}\text { Gross regional product in actual prices, } \\
\text { million UAH }\end{array}$} & \multirow{2}{*}{$\begin{array}{c}\text { Increase } \\
\text { 2018-2014, } \\
\text { million } \\
\text { UAH }\end{array}$} & \multirow{2}{*}{$\begin{array}{c}\text { Coefficient } \\
\text { of growth } \\
2018 / 2014 \text {, } \\
\% \\
\end{array}$} \\
\hline & 2014 & 2015 & 2016 & 2017 & 2018 & & \\
\hline Ukraine & $1,586,915$ & $1,988,544$ & $2,385,367$ & $2,983,882$ & $3,560,596$ & $+1,973,681$ & +224.4 \\
\hline Vinnytsa & 43,990 & 59,871 & 74,411 & 92,427 & 111,498 & $+67,508$ & +253.5 \\
\hline Volyn & 24,195 & 31,688 & 35,744 & 51,972 & 60,448 & $+36,253$ & +249.8 \\
\hline Dnipropetrovsk & 176,540 & 215,206 & 244,478 & 313,830 & 369,468 & $+192,928$ & +209.3 \\
\hline Donetsk & 119,983 & 115,012 & 137,500 & 166,404 & 192,256 & $+72,273$ & +160.2 \\
\hline Zhytomyr & 29,815 & 38,425 & 47,919 & 61,470 & 77,110 & $+47,295$ & +258.6 \\
\hline Zakarpattia & 24,120 & 28,952 & 32,390 & 43,043 & 52,445 & $+28,325$ & +217.4 \\
\hline Zaporizhzha & 65,968 & 89,061 & 104,323 & 130,377 & 147,076 & $+81,108$ & +223.0 \\
\hline $\begin{array}{l}\text { Ivano- } \\
\text { Frankivsk }\end{array}$ & 37,643 & 45,854 & 51,404 & 63,850 & 78,443 & $+40,800$ & +208.4 \\
\hline Kyiv & 79,561 & 104,030 & 128,638 & 157,043 & 198,160 & $+118,599$ & +249.1 \\
\hline Kirovohrad & 28,758 & 38,447 & 46,021 & 53,031 & 64,436 & $+35,678$ & +224.1 \\
\hline Luhansk & 31,393 & 23,849 & 31,356 & 30,285 & 35,206 & $+3,813$ & +112.1 \\
\hline Lviv & 72,923 & 94,690 & 114,842 & 147,404 & 177,243 & $+104,320$ & +243.1 \\
\hline Mykolaiv & 35,408 & 48,195 & 57,815 & 69,371 & 79,916 & $+44,508$ & +225.7 \\
\hline Odesa & 74,934 & 99,761 & 119,800 & 149,530 & 173,241 & $+98,307$ & +231.2 \\
\hline Poltava & 69,831 & 95,867 & 116,272 & 150,904 & 174,147 & $+104,316$ & +249.4 \\
\hline Rivne & 28,724 & 35,252 & 39,469 & 48,836 & 56,842 & $+28,118$ & +197.9 \\
\hline Sumy & 30,397 & 41,567 & 46,287 & 56,530 & 68,489 & $+38,092$ & +225.3 \\
\hline Ternopil & 21,676 & 26,656 & 31,072 & 40,747 & 49,133 & $+27,457$ & +226.7 \\
\hline Kharkiv & 96,596 & 124,843 & 154,871 & 187,454 & 233,321 & $+136,725$ & +241.5 \\
\hline Kherson & 23,250 & 32,215 & 38,743 & 47,868 & 55,161 & $+31,911$ & +237.3 \\
\hline Khmelnytsk & 32,162 & 41,088 & 48,859 & 63,882 & 75,646 & $+43,484$ & +235.2 \\
\hline Cherkasy & 38,466 & 50,843 & 59,412 & 73,176 & 93,315 & $+54,849$ & +242.6 \\
\hline Chernivtsi & 15,049 & 18,506 & 21,239 & 28,591 & 33,903 & $+18,854$ & +225.3 \\
\hline Chernihiv & 28,156 & 36,966 & 43,362 & 56,672 & 70,624 & $+42,468$ & +250.8 \\
\hline Kyiv city & 357,377 & 451,700 & 559,140 & 699,185 & 833,069 & $+475,692$ & +233.1 \\
\hline
\end{tabular}

Source: Calculated on the basis of data (State Statistics Service of Ukraine, 2018).

In Ukraine, the most commonly used hered to by the State Statistics Service of classification of enterprises by number of jobs Ukraine and it meets the criteria used in Euand annual income. This classification is ad- ropean countries (Table 2).

Table 2. Signs of micro, small, medium and large enterprises in Ukraine

\begin{tabular}{|c|c|c|c|c|}
\hline Signs & Micro & Small & Medium & Large \\
\hline Number of jobs & $\leqslant 10$ employees & $\leqslant 50$ employees & $\begin{array}{c}\text { All enterprises that } \\
\text { do not belong to the }\end{array}$ & $\begin{array}{c}\geqslant 250 \text { employ- } \\
\text { ees }\end{array}$ \\
\cline { 1 - 1 } & $\leqslant 2$ million & $\leqslant 10$ million & category of small or & $\geqslant 50$ million \\
Annual income & EUR & EUR & large enterprises & EUR \\
\hline
\end{tabular}

Source: The Verkhovna Rada of Ukraine (2003).

In 2018, the share of micro, small and medium enterprises (SMEs) in Ukraine was over $90 \%$ of the total number of enterprises. SMEs provided more than $60 \%$ of jobs and almost $50 \%$ of value added in the business sector.

More than $50 \%$ of the SME structure is concentrated in wholesale and retail trade. 
The downside is the fact that most SMEs are concentrated in a low value-added sector of the economy. However, the share of SMEs engaged in IT technologies has been growing rapidly over the last five years.

Wholesale and retail trade have the largest share $(43.1 \%)$ in the structure of small and medium enterprises in the Odessa region.

The simplest and easiest to start is a small and micro business. In different regions of Ukraine, the internal factors of small business development may differ, but the external environment is the same. That is why it is advisable to take into account the peculiarities of the external environment of small business development in the regions, which can be analyzed using PEST-analysis (Table 3).

Table 3. PEST-analysis of the external environment of SME development in the regions

\begin{tabular}{|c|c|c|c|}
\hline \multicolumn{2}{|c|}{ Political aspects } & \multicolumn{2}{|c|}{ Economic aspects } \\
\hline Negative & Positive & Negative & Positive \\
\hline $\begin{array}{l}\text { 1. Imperfection of } \\
\text { normative-legal regula- } \\
\text { tion of the sphere of } \\
\text { SME management. }\end{array}$ & $\begin{array}{l}\text { 1. Historically } \\
\text { accumulated base } \\
\text { and experience of } \\
\text { legal regulation of } \\
\text { SMEs. }\end{array}$ & $\begin{array}{l}\text { 1. Low level of solvency } \\
\text { of the population and } \\
\text { significant fluctuations } \\
\text { in market conditions. }\end{array}$ & $\begin{array}{l}\text { 1. The trend of } \\
\text { GDP and GRP } \\
\text { growth in absolute } \\
\text { terms. }\end{array}$ \\
\hline \multirow[t]{4}{*}{$\begin{array}{l}\text { 2. Imperfect system of } \\
\text { local regulation of } \\
\text { SMEs. }\end{array}$} & \multirow{4}{*}{$\begin{array}{l}\text { 2. National and } \\
\text { territorial pro- } \\
\text { grams to support } \\
\text { SME develop- } \\
\text { ment. }\end{array}$} & $\begin{array}{l}\text { 2. Low level of invest- } \\
\text { ment capacity and in- } \\
\text { vestment attractiveness. }\end{array}$ & $\begin{array}{l}\text { 2. Relatively low } \\
\text { inflation rate. }\end{array}$ \\
\hline & & $\begin{array}{l}3 \text { Increasing the cost of } \\
\text { energy resources. }\end{array}$ & \multirow[t]{3}{*}{$\begin{array}{l}\text { 3. Relatively stable } \\
\text { exchange rate. }\end{array}$} \\
\hline & & $\begin{array}{l}\text { 4. High interest rates on } \\
\text { credit resources. }\end{array}$ & \\
\hline & & $\begin{array}{l}\text { 5. Rising unemployment } \\
\text { due. }\end{array}$ & \\
\hline \multicolumn{2}{|c|}{ Social aspects } & \multicolumn{2}{|c|}{ Scientific and technological aspects } \\
\hline Negative & Positive & Negative & Positive \\
\hline $\begin{array}{l}\text { 1. Demographic crisis: } \\
\text { a sharp decline in birth } \\
\text { rates, increased mor- } \\
\text { tality and lack of natu- } \\
\text { ral increase; intensifi- } \\
\text { cation of migration } \\
\text { processes. }\end{array}$ & $\begin{array}{l}\text { 1. Significant } \\
\text { human resources. }\end{array}$ & $\begin{array}{l}\text { 1. Low level of innova- } \\
\text { tion: a small share of } \\
\text { enterprises engaged in } \\
\text { innovation and produc- } \\
\text { ing innovative products. }\end{array}$ & $\begin{array}{l}\text { 1. Existence of the } \\
\text { state program of } \\
\text { deregulation and } \\
\text { development of } \\
\text { business. }\end{array}$ \\
\hline $\begin{array}{l}\text { 2. Imbalance of supply } \\
\text { and demand in the la- } \\
\text { bor market. }\end{array}$ & $\begin{array}{l}\text { 2. Availability of } \\
\text { social protection } \\
\text { programs. }\end{array}$ & $\begin{array}{l}\text { 2. Imperfect system of } \\
\text { financing the costs of } \\
\text { innovation. }\end{array}$ & $\begin{array}{l}\text { 2. Focus on innova- } \\
\text { tion and sustaina- } \\
\text { bility. }\end{array}$ \\
\hline
\end{tabular}

Source: Summarized by the author.

As you know, PEST-analysis "is designed to identify political ( $\mathrm{P}$ - political), economic (E - economic), social ( $\mathrm{S}$ - social) and technological ( $\mathrm{T}$ - technological) aspects of the environment that affect the company's business" (Wikipedia. Free encyclopedia, 2019). PEST-analysis of the external envi- ronment of SME development in the regions does not take into account environmental aspects. Therefore, despite the general orientation of the national economy to sustainable development, it should be appropriate for business to comply with the requirements of environmental safety, which in turn will pro- 
vide an opportunity to meet the needs not only for present but also for future generations.

In the direction of ensuring environmental safety, it is necessary to ensure monitoring of the levels of: emissions and discharges of pollutants, fertility of agricultural lands, etc. In addition, penalties for violating environmental requirements for doing business should be regulated. Cash receipts to the budgets of territorial communities from penalties for non-environmental way of doing business can be used for community development and the creation of waste processing plants.

The problem of garbage needs significant attention and an urgent solution at the level of regions and individual territorial communities, as Ukraine has accumulated more than 50 million cubic meters of waste, most of which cannot be recycled, but are simply in landfills and landfills. The level of solid household waste per capita is only growing from year to year. In order to solve the problem of garbage in Ukraine, it is expedient to use the experience of European countries, in particular the experience of Sweden in processing waste for fuel and raw materials for production and the experience of Britain in processing food waste for energy using anaerobic digestion technology.

"Yes, Sweden recycles $99 \%$ of all waste from which fuel and raw materials are produced for production. The country is so successful in this area that it imports garbage from other countries. And pay attention! The Swedes do not buy this junk at all, on the contrary, the countries - exporters pay them extra for its use. The experience of Britain, which converts food waste into energy through "anaerobic digestion", is also interesting. India, which recently suffocated from garbage, came up with and implemented the idea of using plastic to produce asphalt. Now thousands of kilometers of roads have been built in the country with the help of these raw materials. And there are many such examples that show how attentive the world's leading countries are to garbage. In today's world, waste has become a valuable material that brings significant profits" (Rokhova, 2019).

The study of the characteristics of the dynamics of sales of medium and small enterprises of Odessa region shows a decline, which is evidence of the need to take additional measures to stimulate the development of SMEs in the region.

The generalizing economic characteristic of regional development is the gross regional product (GRP). The average level of GRP in 2018 was $142,423.84$ million UAH. Only nine regions with GRP values were above average - Dnipropetrovsk, Donetsk, Zaporizhzhia, Kyiv, Lviv, Odesa, Poltava, Kharkiv regions and the city of Kyiv. The remaining fourteen regions are characterized by below-average GRP levels.

Gross regional product in the economic literature is used as a modern characteristic of territorial, sectoral and functional heterogeneity. GRP is a characteristic of territorial development and, at the same time, characterizes the efficiency of the national economy.

The dynamics of the gross regional product of Odesa region for 2014-2018 shows growth in absolute terms. However, the index of physical volume of GRP for 2014 and 2015 did not exceed $100 \%$.

After the decline in the physical volume of GRP of Odesa region in 2014 and 2015, growth was achieved mainly due to an increase in industrial production. Over the last 4 years, there has been an ambiguous situation in the development and efficient functioning of the industry. Thus, in 2014-2015, the volume of output at industrial enterprises decreased to $96.1 \%$. 2016-2017 was marked by a significant increase in production, thanks to which the region broke into the leaders and lasted until 2018 - 1st place among the regions of the country. In 2018, the production of food products decreased significantly, the share of the sub-sector in the total volume is the largest and amounts to more than $40.0 \%$.

In 2018, there was a decrease in industrial output in the Odesa region due to the decline in production of oil, animal fats, flour. 
In addition, in the second half of 2018, the volume of chemical products decreased due to the unstable production situation at PJSC “Odeskyi Port Plant” for the production of urea and ammonia.

Despite a certain instability of the industrial sector of Odesa region for 2014-2018, there was an increase in sales of this sector. The value of sales of industrial products of Odesa region in 2018 amounted to 58,166.5 million UAH. The largest share in the sale of industrial products was occupied by food.

The commodity structure of industrial production has a significant share in the production of unrefined sunflower oil, vegetable and fruit juices, bread and bakery products, flour, wine products, plastic products, medical equipment and more. The main markets for industrial products are Turkey, the Russian Federation, Spain, China, Moldova, Liberia, India, Saudi Arabia, Indonesia, Italy, Egypt.

\section{Conclusions.}

It is investigated that from 2016 until in Ukraine there was a certain economic recovery, which is confirmed by the growth of consumption and income, as well as the growth of consumer lending and remittances. But in 2018, there was a decrease in exports and imports of goods and services. Exports decreased by $2.8 \%$ of GDP, and imports by $1.9 \%$ of GDP compared to the previous 2017 year. The decline in exports is due to weakening external demand for domestic goods and services. Despite some difficulties, a number of reforms have been implemented in
Ukraine, which have had a positive impact on the economic situation.

Reforms in Ukraine are supported by the international community. In 2018, the IMF provided Ukraine with a reserve loan for a period of 14 months in the amount of 3.9 billion USD. Ukraine received 4.4 billion USD in EU macro-financial assistance US and a loan of 349 million EUR under the World Bank Guarantee to ensure economic development. After the crisis of the economy in 2014, Ukraine managed to restore macroeconomic stability by adhering to flexible exchange rate limits, tight fiscal policy, financial and energy reforms. The signing of the Association Agreement with the EU in 2014 on the establishment of a Deep and Comprehensive Free Trade Area with the EU had a positive impact on Ukraine's economy.

It is investigated that in 2018 the share of micro, small and medium enterprises (SMEs) in Ukraine was over $90 \%$ of the total number of enterprises. SMEs provided more than $60 \%$ of jobs and almost $50 \%$ of value added in the business sector. More than $50 \%$ of the SME structure is concentrated in wholesale and retail trade. The downside is the fact that most SMEs are concentrated in a low value-added sector of the economy. However, the share of SMEs engaged in IT technologies has been growing rapidly over the last five years. Wholesale and retail trade have the largest share $(43.1 \%)$ in the structure of small and medium enterprises in the Odesa region.

\section{References}

Afontsev, S. (2001), "Global management of international economic system: Theoretical aspects", Mirovaya ekonomika i mezhdunarodnye otnosheniya, no. 5, pp. 65-70.

Government portal (2019), "Support small and medium businesses", available at: https://www.kmu.gov.ua/diyalnist/reformi/ekonomichne-zrostannya/pidtrimka-malogo-i-serednogopidpriyemnictva (Accessed 03 August 2019).

Khesin, E. (2005), “World economy: Entering the third millennium”, International Economics, vol. 3, pp. 5-19. Khokhlov, N. (2004), "Globalization of the economy in the perspective of the evolution of property relations", Economy of Ukraine, no. 2, pp. 66-72.

Kramarenko, I. S. (2014), Reinzhynirynh navchalnoho protsesu: vid teorii do praktyky [Reengineering of the educational process: From theory to practice], FOP Shvets VD., Mykolaiv, Ukraine, 64 p. 
Ministry for Communities and Territories Development of Ukraine (2019), "The concept of public policy and the plan for its implementation to achieve goal 10.2. "Ukrainians living in "depressed regions" have sufficient opportunities to develop" the Program of Activities of the Cabinet of Ministers of Ukraine", available at: https://www.minregion.gov.ua/base-law/grom-convers/elektronni-konsultatsiyi-zgromadskistyu/konczepcziya-derzhavnoyi-polityky-ta-plan-2 (Accessed 03 August 2019).

Rokhova, N. (2019), “The garbage problem: From Europe to Ukraine”, available at: https://www.csi.org.ua/news/problema-smittya-vid-yevropy-do-ukrayiny/ (Accessed 03 August 2019).

Shchenin, R. and Smirnov, S. (2005), "International integration associations in the regional spaces of the world”, International economy, no. 5, pp. 22-33.

State Statistics Service of Ukraine (2018), "Gross regional product in 2018", available at: http://www.ukrstat.gov.ua/druk/publicat/kat u/2020/zb/04/zb vrp 2018.pdf (Accessed 03 August 2019).

The Verkhovna Rada of Ukraine (2003), "Commercial Code of Ukraine", available at: https://zakon.rada.gov.ua/laws/show/436-15\#Text (Accessed 03 August 2019).

Wikipedia. Free encyclopedia (2019), "PEST-analysis", available at: https://en.wikipedia.org/wiki/PESTanalysis (Accessed 03 August 2019). 